\title{
Penggunaan Dan Pemaanfaatan Cyberspace Dalam Gerakan Pemikiran Hizbut Tahrir
}

\author{
Ambar Sri Lestari" ${ }^{* 1)}$, Shabrur Rijal Hamka ${ }^{2)}$ \\ ${ }^{1}$ Fakultas Tarbiyah dan Ilmu Keguruan, Institut Agama Islam Negeri \\ Kendari, Indonesia \\ ${ }^{2}$ Pascasarjana Institut Agama Islam Negeri Kendari, Indonesia \\ Koresponden Author: ambarlstr@gmail.com
}

\begin{abstract}
This research aims to analyze the use and utilization of cyberspace as new media (internet) in the movement thought of Hizbut Tahrir at IAIN Kendari. The findings of the situation show that the use and utilization of cyberspace via the internet with the Facebook as one of the social media by either students who follow the activities of the intra or extra campus or who does not enter the organization by taking samples in the first half of the even and odd semester students of 2016/2017nwhich consists of eight classes indicate that they are more panic when it comes to the use of Facebook taking up to 0.89 or $89 \%$. From the use of this social media, then the process of movement of thought against religious doctrine can be done through cyberspace started from the ndividual level, the level of interaction between the individual and community level; cybersociety (virtual community) and finally form a culture (Cyberculture) by a movement of Hizbut Tahrir. The process of religious doctrine is done through several methods, namely: participation, openness, communication, community, dependency/connectedness.
\end{abstract}

Keywords: cyberspace, internet, social media, Hizbut Tahrir

\begin{abstract}
Abstrak
Penelitian ini bertujuan untuk menganalisis penggunaan dan pemanfaatan cyberspace sebagai newmedia (internet) dalam gerakan pemikiran Hizbut Tahrir di IAIN Kendari. Penelitian dilakukan di IAIN Kendari dengan disain penelitian menggunakan metode deskriptif kualitatif dan partisipan dalam penelitian ini adalah mahasiswa yang mengikuti organisasi baik intra,ekstra kampus maupun yang tidak mengikuti organisasi kampus; dosen sebagai tokoh masyarakat maupun dosen yang mengikuti organisasi Hizbut Tahrir dan pimpinan perguruan tinggi. Temuan dilapangan menunjukkan bahwa penggunaan newmedia internet melalui media social facebook digunakan oleh mahasiswa sebanyak $89 \%$ karena facebook lebih familiar pada penggunanya. Pemanfaatan internet melalui media social facebook sebagai sarana penyampaian informasi yang dilakukan dalam proses gerakan pemikiran Hizbut Tahrir dilakukan, melalui 1) cyberspace secara individu, interaksi antar individu dan komunitas; 2) cybersociety melalui masyarakat virtual dan 3) cyberculture melalui pembentukan budaya oleh gerakan pemikiran Hizbut Tahrir dengan simbol dan lainnya. Karakteristik media sosial dalam penyampaian informasi
\end{abstract}


dapat dilakukan melalui beberapa cara yaitu partisipasi, keterbukaan, komunikasi, komunitas, dan ketergantungan/keterhubungan.

Kata kunci: cyberspace; internet, media sosial; Hizbut Tahrir.

\section{A. Pendahuluan}

Internet sebagai sarana komunikasi dan publikasi yang menghadirkan situs jejaring sosial (social network site) seperti Facebook, Twitter, MySpace memberikan warna berbeda dalam kehidupan masyarakat. Tidak bisa dinafikan bahwa para mahasiswa yang memang pada tahap proses pencarian identitas diri belajar dan mengenal banyak hal, sehingga sangat mungkin menjadi sasaran yang paling strategis untuk mengikuti gerakan pemikiran keagamaan yang sudah diikuti mulai dari sekolah menengah atas sebelumnya dan mengikuti kegiatan OSIS keagamaan. Khususnya mahasiswa yang memiliki jangkauan pergaulan luas dan relatif otonom, dapat dijadikan sarana untuk memproliferasi paham-paham radikal yang diperjuangkan oleh paham agama tertentu. Sehingga dapatlah kita jumpai kaum muda ini terjerat dalam pemikiran terhadap paham keagamaan yang akhirnya mulai mengarah pada radikalisme secara aksi.Saat ini kehadiran media sosial seperti Facebook, Twitter, Blog, Youtube dan layanan pesan misalnya WhatsApp sangat memudahkan kelompok tertentu dapat mudah menyebarkan propaganda, melakukan sosialisasi dan diseminasi ideology ekstrimisme dan radikalismeyang disampaikan melalui publikasi video. Sebagaimana yang dijelaskan oleh Neil Postman dalam Straubhaar ${ }^{1}$, bahwa kehadiran teknologi di tengah masyarakat dapat membentuk suatu budaya yang disebut dengan technopoly dimana teknologi didewakan dan diserahkan untuk mengontrol segala aspek kehidupan masyarakat. Seperti halnya media sosial dikatakan sebagai transformasi kebudayaan, khususnya dalam interaksi sosial menurut Thurlow ${ }^{2}$ yaitu bagaimana kita melihat di masa sekarang bahwa identitas, relationship dan komunitas dapat dibentuk melalui media sosial, bagaimana kita hidup dan bekerja sangat tergantung dengan teknologi.

Teori yang dipergunakan dalam penelitian ini adalah teori new media yang dikemukakan oleh Mark Poster dalam bukunya "What's The Matter With The Internet". Dalam kajiannya terhadap internet, Mark Poster

${ }^{1}$ Straubhaar, J., LaRose, R., and Davenpo, L, Media Now: Understanding Media, Culture, and Technology, 7th edition, Wadsworth, Cengage Learning, United States of America, 2010, h. 50.

${ }^{2}$ Thurlow, C., Lengel, L., and Tomic, A, Computer Mediated Communication Social Interaction And The Internet, (London, Thousand Oaks and New Delhi: Sage Publications, 2004), h. 2. 
mengatakan bahwa internet dipandang sebagai suatu arena dan ruang konfigurasi dan konstruksi identitas yang didalamnya bisa terjadi suatu relasi dan reaksi terhadap kuasa ${ }^{3}$. Dalam hal ini, Poster mengintrepretasikan internet sebagai suatu public sphere, dimana interaktifitas, interkonektifitas, dan fluiditas dalam penggunaan internet memberikan ruang terbuka bagi masyarakat luas sebagai bentuk adanya ruang publik. Everett M. Rogger dalam Burhan ${ }^{4}$ menjelaskan bahwa dalam hubungan komunikasi dimasyarakat, terdapat beberapa tahap perkembangan komunikasi yaitu tulis, cetak, komunikasi dan komunikasi interaktif. Sedangkan social media menurut Antony Mayfield ${ }^{5}$ merupakan suatu sarana komunikasi dimana masyarakat dapat berpartisipasi melalui pesan online dan komunikasi virtual.

Beberapa kajian terdahulu diantaranya yang menjelaskan tentang penggunaan media televisi/elektronik nasional ${ }^{6}$, mengungkapkan bahwa revolusi digital telah mengubah perilaku orang dalam banyak hal, termasuk dalam memperoleh informasi yang dapat dilakukan melalui interaksi individu, kelompok, sampai pada sebuah badan pengolahan informasi. Penelitian Asep Muhammd Iqbal ${ }^{7}$ menjelaskan bahwa internet digunakan untuk mempromosikan identitas kolektif mereka dimana internet merupakan media dakwah yang dapat digunakan untuk menyebarkan identitas salafi melalui publikasi artikel-artikel dan fatwa-fatwa yang berkaitan dengan ideologi salafisme, aturan berperilaku, jihad, dan politik.

Penelitian Muhammad Aliakov ${ }^{8}$ mengemukakan tentang latar belakang tindakan radikalisme yang dipicu oleh beberapa faktor diantaranya faktor kemiskinan, kebodohan, politik, psikologis, doktrin radikalisme. Selanjutnya Abdul Munip ${ }^{9}$ mengemukakan dalam hasil penelitiannya tentang penyebab

${ }^{3}$ Mark Poster, What's The Matter With The Internet (Minneapolis: University of Minoseta Press. 2001), h. 20.

${ }^{4}$ Burhan Bungin, Sosiologi Komunikasi Teori, Paradigma dan Diskursus Teknologi Komunikasi di Masyarakat, (Jakarta: Kencana. 2006), h. 111-112.

5 Antony Mayfield, What is Social Media? (London: Crossing. United Kingdom, http://www.iCrossing.com/ebooks.2008), h.5.

${ }^{6}$ Yuni Rafta, "Sosial Network Analysis Dalam Melihat Kecenderungan Pemberitaan Pada Akun Twitter "detikcom" dan "Metro_TV", Jurnal Khazanah, Vol 6 No. 2, (Januari 2014), h. 69.

${ }^{7}$ Asep Muhammd Iqbal, “Agama dan Adopsi Media Baru: Penggunaan Internet Oleh Gerakan Salafisme di Indonesia”, Jurnal Komunikasi Indonesia, Vol 2. No.2, (Oktober 2013), h. 81.

${ }^{8}$ Muhammad Aliakov, Berkembangnya Radikalisme di Perguruan Tinggi. STMIK AMIKOM Yogjakarta. Jurusan Sistem Informasi. reseacrh.amikom.ac.id http:www/researchgate.net/publication

${ }^{9}$ Abdul Munip. "Menangkal Radikalisme Agama Di Sekolah". Jurnal Pendidikan Islam 09/2014;1 (2):159. DOI: 10.14421/jpl.2012.12.159-181. https://reseacrhgate.net/publication 
radikalisme agama seperti pemahaman agama yang literal yang masih ada di masyarakat. Penelitian Arindra Khrisna ${ }^{10}$ menemukan bahwa terdapat tiga jenis propaganda, yaitu propaganda putih, abu-abu dan hitam. Propaganda hitam merupakan bentuk penyebaran informasi secara tertutup dan menyesatkan. Propaganda putih seperti yang biasa dilakukan media yang berpihak pada suatu kepentingan politik atau kebijakan tertentu yang kegiatannnya terbuka. Propaganda abu-abu adalah kegiatannya tertutup, seperti memanfaatkan wartawan untuk menulis berita.

Penelitian Leni Winarni ${ }^{11}$ menjelaskan bahwa media internet mengambil porsi dan peranan yang sangat besar dalam memberikan informasi kepada publik/masyarakat terutama terkait sebuah ideologi. Hal ini diperparah dengan fakta bahwa perekrutan kaum muda dalam organisasi-organisasi radikal banyak dilakukan dengan menggunakan media internet. Selain itu penelitian Salvatore Simarmata ${ }^{12}$ menyatakan bahwa ruang publik (public sphere) merupakan ruang bagi kepentingan umum yang lebih luas. Internet dan world wide web merupakan dua elemen utama yang memungkinkan teknologi media baru tersebut menjadi media komunikasi yaitu Facebook, Tweeter sebagai bagian dari media baru. Muhammad Mustaqim ${ }^{13}$ dalam penelitiannnya menyatakan bahwa ketika individu-individu mampu mempengaruhi pendapat dan keputusan untuk kepentingan publik maka ruang publik mulai bekerja. Dimana tiap individu melakukan komunikasi, berafiliasi, memberi saran dan pandangan secara kritis, saling mempengaruhi, dan membangun dimensi sosial publik.

Studi ini difokuskan pada indoktrinasi paham agama dalam gerakan pemikiran mahasiswa IAIN Kendari yang mengikuti kegiatan organisasi intra kampus seperti LDK UPMI dan UKM-KOMPA pada penggunaan newmedia melalui internet yang menjadi sebuah ruang cyberspace untuk dimanfaatkan dimana perguruan tinggi Islam menjadi ruang bagi gerakan pemikiran oleh organisasi politik yang mengarah pada pemikiran radikalisme. Penulis menggunakan metode deskriptif kualitatif yang dilakukan dengan teknik observasi, yaitu utuk mengetahui keterlibatan mahasiswa maupun dosen

\footnotetext{
${ }^{10}$ Arindra Khrisna. Kontra propaganda Radikalisme di Media Sosial. https://www.academia.edu/21805200/KONTRAPROPAGANDA_RADIKALISME_D I MEDIA SOSIAL

${ }^{11}$ Leni Winarni, "Media Massa dan Isu Radikalisme Islam”, Jurnal Komunikasi Massa. Vol 7.No.2, Juli 2014, h.164.

${ }^{12}$ Salvatore Simarmata, "Media Baru, Ruang Publik Baru dan Transformasi Komunikasi Politik di Indonesia", Jurnal INTERACT, Vo.3 No.2, (November, 2014), h.18.

${ }^{13}$ Muhammad Mustaqim, "Pergulatan Pemikiran Islam Di Ruang Publik Maya (Analisis terhadap Tiga Website Organisasi Islam di Indonesia)", Jurnal Penelitian, Vol. 7, No. 2, Agustus 2013, h. 255-258.
} 
dalam gerakan pemikiran Hizbut Tahrir melalui akun media social yang dimiliki, wawancara untuk menjaring informasi dari pada informan/narasumber baik mahasiswa aktif maupun alumni dan dosen $(\mathrm{HB})^{14}$ yang ikut dalam organisasi Hizbut Tahrir serta dilakukan fokus group discussion untuk mengetahui pandangan-pandangan mahasiswa dalam melihat berbagai macam fenomena yang ada terkait dengan gerakan radikalisme.

\section{B. Pemanfaatan dan Penggunaan Cyberspace Masyarakat Kampus IAIN Kendari}

Sebagaimana dijelaskan Castells mengenai konstruksi identitas dan hubungannya dengan konteks masyarakat jaringan ${ }^{15}$ serta Hassan ${ }^{16}$ mengenai hubungan antara media, identitas dan politik yang mengatakan bahwa masyarakat jaringan terbentuk berhubungan dengan aspek ekonomi, sosial, budaya dan politik. Internet adalah bagian dari kemajuan teknologi informasi dan kemunculan masyarakat jaringan sebagai konsekuensinya tidak bisa dipisahkan dengan kapitalisme. Amar Ahmad ${ }^{17}$ menyatakan hubungan antara teknologi dan masyarakat yang memandang media merupakan refleksi keinginan dari sebagian besar masyarakat.

Dari hasil temuan dilapangan menunjukkan penggunaan internet oleh mahasiswa banyak didominasi media social facebook sebesar $89 \%$, hal ini didasarkan atas mayoritas pengguna media social yangterbanyak adalah pada mediasosial facebook yang memang lebih familiar oleh penggunanya karena kelengkapan menu yang disajikan oleh facebook, sedangkan penggunaan Instagram, Tweeter dan Friendster tidak banyak digunakan oleh mahasiswa. Selain itu, Blog digunakan sebanyak 57\%, sedangkan pemanfaatan media social melalui facebook dari mahasiswa yang mengikuti gerakan organisasi intra kampus, yaitu Lembaga Dakwah Kampus (LDK) banyak digunakan untuk menginformasikan organisasi Hizbut Tahrir yang diikuti sehingga dapat memperluas jaringan organisasi melalui internet, khususnya dari media

14 HB.Dosen Fakultas Ushuludin dan Dakwah. Pengurus Hizbut Tahrir Sulawesi Tenggara.

${ }^{15}$ Manuel Castells, The Power of Identity, Second Edition With A New Preface, WileyBlackwell, 2010), h. https://www.researchgate.net/publication/280831282_Networks_in_Manuel_Castells' theor y_of the network society

${ }^{16}$ Hassan Robert, Media, Politics and the Network Society, (Open University Press, 2004), h. 18. https://cryptome.org/2013/01/aaron-swartz/Media-Politics-Network.pdf

${ }^{17}$ Amar Ahmad, "Dinamika Komunikasi Islami di Media Online", Jurnal Ilmu Komunikasi, Vol.11 No.1, Januari-April 2013, h. 44-58. 
social facebook. Berikut bagan organisasi kemahasiswaan di kampus IAIN Kendari sebagaimana yang telah teramati dilapangan.

Bagan 1;Bagan Organisasi Kemahasiswaan Kampus IAIN Kendari

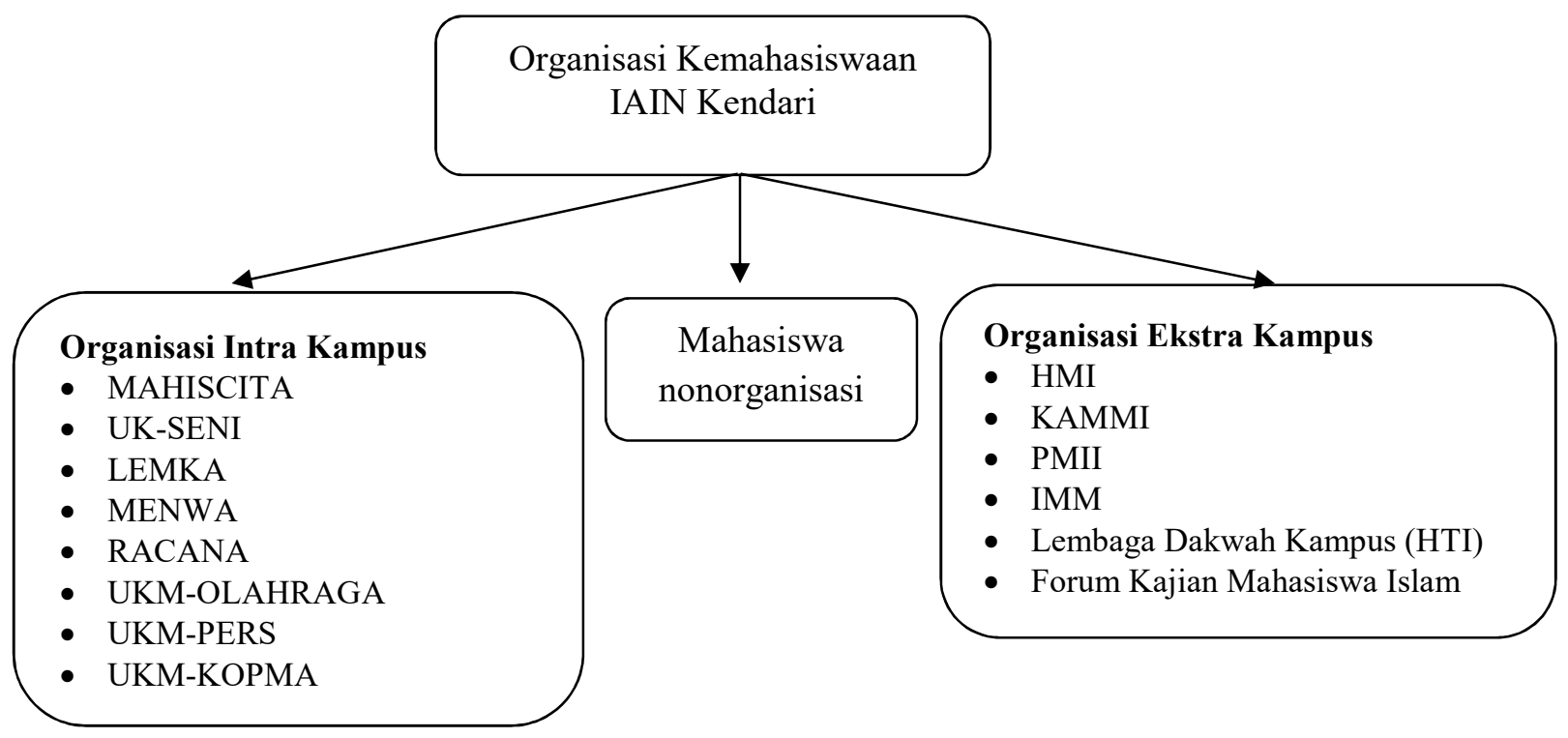

Dari temuan-temuan dilapangan dapat dikategorisasikan berdasarkan data yang diperoleh beberapa aspek yang menjadi identitas dari gerakan pemikiran organisasi Hizbut Tahrir di IAIN Kendari, yaitu diantaranya:

1. Lembaga Dakwah Kampus (LDK) merupakan suatu unit kemahasiswaan yang diikuti oleh mahasiswa di IAIN Kendari yang mengarah pada paham agama

2. Koperasi Mahasiswa (KOPMA) merupakan unit koperasi yang di organisir oleh mahasiswa IAIN Kendari, namun lebih banyak diikuti oleh mahasiswa yang mengikuti organisasi intra kampus LDK sehingga digeneralisasi bahwa KOPMA adalah sama dengan LDK

Dari data tersebut dapat dijelaskan bahwa gerakan pemikiran Hizbut Tahrir yang diikuti mahasiswa khususnya pada organisasi intra kampus, yaitu yang mengikuti organisasi LDK UPMI dan UKM-KOPMA pada akun facebooknya akan terhubung melalui jaringan interaksi antar individu yang memiliki pandangan yang sama terhadap materi paham keagamaan tertentu dalam hal ini adalah gerakan pemikiran Hizbut Tahrir yang diikuti beberapa mahasiswa sebagai berikut: 
$\mathrm{ZYN}^{18}$ dalam akun facebooknya mengunggah postingan "KIMA Konferensi Indonesia Milik Allah" yang diselenggarakan di Auditorium IAIN Kendari pada tanggal 6 Juni 2015 oleh LDK UPMI IAIN Kendari. Selain itu ada poster lainnya seperti "Rapat dan Pawai Akbar 1436H Bersama Umat Tegakkan Khilafah" diselenggarakan tanggal 17 Mei 2015 di Kota Kendari. Poster lainnya adalah "Indonesia Tidak Butuh Reformasi Jilid II saatnya Revolusi Islam Mahasiswa Bersatu tegakkan Khilafah" oleh Gema Pembebasan; "Katakan Kepada Kaum Munafik, Kafir dan Kawan-kawan Khilafah Pasti Berdiri". Dari temuan ini maka dapat dimaknai bahwa LDK IAIN Kendari cenderung mengarah pada gerakan pemikiran organisasi Hizbut Tahrir sehingga memberikan ruang bagi organisasi politik ini masuk dalam ranah akademisi, sebagaimana yang juga banyak ditemukan di kampus-kampus perguruan tinggi Islam lainnya.

Data lain menyebutkan bahwa beberapa mahasiswa telah terpapar ajakan untuk menegakan khilafa, diantarnya yang terjadi pada mahasiswa $\mathrm{AJN}^{19}$ dari beberapa foto yang diunggahnya, seperti pada poster "Sekolah Pemikiran Islam oleh Gema Pembebasan tanggal 14-15 Mei 2016 oleh Gema Pembebasan Komisariat UIN SUKA Jogjakarta". $\mathrm{RG}^{20}$ dalam postingan tulisannya mengunggah "Rezim tak bisa bungkam nalar kritis mahasiswa, pergerakan mahasiswa ideologis tak kan terhalau apapun bentuk pembungkamannya. Biidznillah, gerakan mahasiswa pembebasan akan tetap tegar dan konsisten on the right track dengan ideologi Islam, itulah senjata kami yang akan menghancurleburkan hegemoni kapitalisme demokrasi, melumatnya sampai tak bersisa". Selain itu postingannnya tentang "Pemerintah lewat BNPT rupanya hendak mengembalikan negeri ini ke zaman represif orde baru ketika menginstruksikan pemblokiran beberapa situs Islam. Sungguh ini bagian dari usaha membungkam nalar kritis rakyat dengan bertopengkan "Radikalisme \& Isu Bahaya ISIS". Sesungguhnya ancama dan musuh utama negeri ini adalah Neo Imperialisme \& Neo Liberalisme ala Kapitalisme Demokrasi”.

$\mathrm{DN}^{21}$ dalam foto yang diunggah beberapa poster, diantaranya "Inilah Jalan Dakwahku" Hizbut Tahrir; "Ikuti dan Sukseskan Studi Islam dan Peradilan PILKADA untuk siapa? Oleh HTI Chapter STAIN Kendari tanggal

${ }^{18}$ ZYN, mahasiswa aktif sebagai Divisi Multimedia di LDK IAIN Kendari Fakultas Tarbiyah dan Ilmu Keguruan.

19 AJN sebagai Maktab I'lamiy Hizbut Tahrir, kuliah di UIN SUKA Yogjakarta mengambil konsentrasi Islamic Law, Alumi STAIN Sultan Qaimuddin.

${ }^{20}$ RG.Kuliah di Pascasarjana UIN Maliki Malang, Alumni STAIN Kendari Jurusan Kependidikan Islam.

${ }^{21}$ DN, Alumni STAIN Kendari Jurusan PAI 2011-2012. 
22 April 2012. Dalam hubungan pertemananya, ia berteman dengan $\mathrm{DH}^{22}$, yang hampir semua posting foto yang diunggah berisi tentang Hizbut Tahrir. Masih ada banyak lagi komunitas pertemanan yang terhubung dalam komunitas HT.

$\mathrm{AW}^{23}$ dalam postingan tulisannya di facebook mengatakan tentang "Cara yang syar'i untuk mendirikan khilafah". Pada laman HTI, yaitu pada http://hizbut-tahrir.or.id/2016/05/08cara-yang-sariy-untuk-

mendirikankhilafah/ banyak sekali yang menyukai laman ini, diantaranya adalah $\mathrm{AD}^{24}$. Pada akun facebook gerakan HTI, yaitu http://www.hizbuttahrir.or.id/ ini banyak memposting tulisan-tulisan, maupun video untuk mengenalkan serta mengajak umat akan kebenaran tegaknya, termasuk beberapa koleksi foto HTI. Akun facebook lainnya yaitu " Media daerah muslimah Hizbut Tahrir kendari" banyak memposting tulisan dari kegiatankegiatan Muslimah DPD II MTHI wilayah Sultra dengan tema " Menjadi Pembela Islam dalam memperjuangkan Syariah dan Khilafah" yang berlangsung pada tanggal 3 November 2013 di Sekretariat MHTI Sulawesi Tenggara di Maktab Mandonga. Kegiatan ini dihadiri mulai dari ibu rumah tangga, pelajar, mahasiswa, guru lebih dari 80 muslimah dengan nara sumber Nur Wahidah, S.Si (MTHI Sultra). RA ${ }^{25}$ dalam postingan tulisannya mengenai "Bahaya Liberalisme dan Deradikalisasi Dibalik Perkemahan Rohis". Berita tentang perkemahan Rohis yang digagas oleh Kemenag melaui Direktorat Pendidikan Agama Islam (PAI) pada 2-6 Mei 2016 diselenggarakan di Bumi Perkemahan Cibubur dan diikuti oleh 1.800 siswa SMA dan SMK seluruh Indonesia dengan tema "Membangun Generasi Muda yang Ramah dan Bermartabat" sebagaimana diunggah pada laman http://www.visimuslim.net/2016/05 bahaya-liberalisme-danderadikalisasi.html.

$\mathrm{AM}^{26}$ dalam postingannya menuliskan "Demokrasi, sudah terlihat jelas keburukannya tapi masih saja ada manusia berakal yang mengagungagungkannya" Bersama MI, ia membagikan wacana tentang Wawasan Kebangsaan HTI pada hizbut-tahrir.or.id. $\mathrm{AQ}^{27}$ dalam postingannya bersama AR melalui LDK UPMI IAIN Kendari mengajak untuk mengikuti kegiatan mingguan dengan tema Islam Moderat yang diadakan setiap sabtu jam 09.00 di pelataran gedung F kampus IAIN Kendari dan sebagai pemateri adalah AS

\footnotetext{
${ }^{22} \mathrm{DH}$ bekerja di Hizbut Tahrir, kuliah di Jurusan Teknik Industri UII Yogjakarta.

${ }^{23}$ AW, Ketua HTI DPD II Kota Kendari.

${ }^{24}$ AD.Alumi FKIP MPI IAIN Kendari 2016. LDK UMPI IAIN Kendari.

${ }^{25}$ RA. Alumni IAIN Kendari.

${ }^{26}$ AM. Alumni STAIN Kendari.

${ }^{27}$ AH. Mahasiswa FEBI IAIN Kendari semester VIII 2016
} 
semester VIII dan dimoderatori oleh AR dari FTIK PAI semester VIII. Selanjutnya postingan lainnya adalah mengenai info dari LDK UPMI IAIN Kendari menganai acara Diskusi Publik dengan tema "Selamatkan Intelektual Muslim Dari Bahaya Islam Moderat" bertempat di gedung FEBI Lt.1 ruangan 101 dengan tema "Jadilah intelektual dan wujudkan perubahan, raih kemenangan selamtkan Agama Allah".

Hasil wawancara dengan $\mathrm{HB}^{28}$ menyatakan bahwa ia mengikuti organisasi politik Hizbut Tahrir sejak ia bertugas di STAIN Sultan Qaimuddin Kendari dari tahun 2009 hingga sekarang menjadi IAIN Kendari. Menurutnya, pemikiran Hizbut Tahrir yang mengusung penegakan khilafah memang baik dilakukan karena saat ini sistem pemerintahan di Indonesia sudah jauh melenceng dari syariah Islam. Ia sependapat dengan konsep khilafah karena itulah solusi yang terbaik dari semua persoalan bangsa yang ada sekarang ini. Menanggapi organisasi intra seperti LDK yang juga merupakan Pembina, ia memiliki pandangan yang sama dengan pemikiran Hizbut Tahrir, ia setuju karena khilafah sesuai dengan tuntutan dalam AlQur'an dan As-Sunnah. $\mathrm{AO}^{29}$ mahasiswa yang mengikuti LDK menyatakan bahwa pandangan LDK dan HT sama yakni menjalankan segala ketentuan sesuai syariat Islam. $\mathrm{AM}^{30}$ mengatakan bahwa ia mengenal dan mengikuti Hizbut Tahrir melalui kegiatan rohis sejak di Aliyah. Di bangku kuliah, ia mengikuti organisasi intra kampus LDK, dimana ia bertemu dengan banyak kawan seperjuangan dan sependapat dengan pemikiran penegakan khilafah di bumi nusantara, meskipun melalui banyak rintangan dalam mewujudkannya.

Hasil temuan melalui pengamatan pada media sosial facebook yang banyak di gunakan oleh mahasiswa, bisa dijelaskan bahwa organisasi intra kampus melalui Lembaga Dakwah Kampus merupakan citra diri dari lembaga ektra kampus, yaitu Hizbut Tahrir. Mahasiswa yang berada dalam kelompok ini pada media sosialnya, terutama facebook pasti akan terhubung melalui pertemanan dengan orang-orang yang memiliki pandangan yang sama dengan gerakannya, yaitu pada organisasi Hizbut Tahrir. Dari akun facebook, seorang mahasiswa IAIN yang aktif di Hizbut Tahrir dalam pertemanannya akan saling terhubung sekalipun telah menjadi alumni. Seperti halnya dalam postingan tulisan yang diunggah pada facebook seperti "Demokrasi......Demokrasi, sudah terlihat jelas keburukannya tapi masih saja

${ }^{28}$ HB. Dosen Fakultas Ushuludin dan Dakwah. Pengurus Hizbut Tahrir Sulawesi Tenggara. Wawancara via telepon tanggal 10 Juni 2016.

${ }^{29}$ AO. Mahasiswa FTIK IAIN Kendari semester XI, mengikuti HT melalui LDK. Wawancara tanggal 7 Juni 2016.

30 AM. Alumni IAIN Tahun 2015 Jurusan Tarbiyah mengikuti LDK di kampus. Wawancara tanggal 23 September 2016. 
ada manusia berakal yang mengagung-agungkannya......, "Selamatkan Intelektual Muslim Dari Bahaya Islam Moderat", ada pada atribut, simbol, bahkan propaganda Hizbut Tahrir yang juga menyudutkan ideologi dasar negara seperti Pancasila dan Demokrasi seperti kalimat No-Demokrasi, sehingga hal ini jelas memperlihatkan ketidaksepahaman organisasi politik Hizbut Tahrir pada pemerintahan di Indonesia. Selain itu dapat dibaca postingan tulisan-tulisan yang disampaikan menunjukkan dengan jelas sistem dan ideologi yang sudah berlangsung selama ini tidak sejalan dengan pemahaman kelompok Hizbut Tahrir yang justru ingin menegakkan Khilafah di Indonesia, yang mana jelas bertentangan dengan dasar negara Indonesia.

Temuan dilapangan terhadap hasil pengamatan pada media sosial melalui akun facebook mahasiswa bahwa indoktrinasi paham agama melalui tingkat individu (cyberspace) akan disebarluaskan melalui tingkat interaksi antar individu (cybersociety) kemudian membentuk sebuah komunitas yang membudaya dalam lingkungan organisasi politik Hizbut Tahrir (cyberculture) melalui simbol-simbol dan gerakan pemikiran organisasi tersebut. Media sosial yang digunakan sebagai sarana menciptakan komunitas oleh para anggota dalam pertemanan organisasi Hizbut Tahrir (cyberculture).

Penyampaian visi-misi dari gerakan pemikiran organisasi Hizbut Tahrir dapat dilakukan melalui beberapa cara; diantaranya partisipasi yaitu setiap individu bisa mengikuti kegiatan dakwah yang disampaikan baik melalui personal maupun kajian-kajian serta seminar/pertemuan. Kegiatan organisasi ini dilakukan secara terbuka dan menganut prinsip keterbukaan untuk masyarakat umum. Sistem interaksi yang dibangun melalui komunikasi personal hingga struktural, sehingga apa yang menjadi visi dapat tersampaikan pada public. Keanggotaan dari organisasi ini akhirnya membentuk suatu komunitas yang mengakar secara prinsip dan pemikiran. Setiap individu yang telah memahami doktrin organisasi ini akan memiliki ketergantungan maupun keterhubungan yang kuat dimanapun mereka berada, karena telah menjadi satu komunitas dalam organisasi Hizbut Tahrir.

Temuan dilapangan dianalisis berdasarkan hasil penelitian yang direlease dan diedarkan oleh Badan Intelegen Nasional (BIN) ${ }^{31}$ bahwa ideologi Islam berhaluan neo-fundamentalis kini popular disebut ideologi Islam transnasional yang dapat dicirikan sebagai berikut 1) bersifat antar negara (transnasional), 2) konsep gerakan tidak lagi bertumbu pada nation-state melainkan konsep ummah, 3) didominasi oleh corak pemikiran skriptualis, fundamentalisme atau radikal dan 4) secara parsial mengadaptasi gagasan dan instrumen modern. Beberapa ideologi dan organisasi Islam yang masuk

${ }^{31}$ Badan Inteligen Nasional, Gerakan Islam Transnasional dan Pengaruhnya di Indonesia, BIN, h.7-9. 
dalam kelompok ini adalah Hizbut Tahrir, Salafi Dakwah, Salafi Sururi, Jama'ah Tabligh serta Syi'ah. Dijelaskan bahwa proses radikalisasi ${ }^{32}$ berjalan melalui beberapa tahapan, yaitu proses diawali dengan merubah individu dari seseorang dengan pemahaman non-radikal menjadi individu dengan pemahaman radikal yang dapat dijadikan sebagai kader organisasi yang memiliki sifat radikal, bahkan dapat dijadikan kader teroris. Hal ini dilakukan melalui perekrutan atau partisipasi individu. Setelah itu dilanjutkan ke tahap pengidentifikasian diri, yaitu melalui cara target dibuat kehilangan identitas diri, sehingga berada pada kondisi tidak stabil. Tahap indoktrinasi merupakan tahapan dimana target diberi pemahaman-pemahaman secara intensif mengenai paham dan ideologi tertentu sehingga target menjadi percaya dan yakin sepenuhnya terhadap ajaran yang diterima. Proses transformasi juga tidak hanya bersifat individu saja, namun juga kelompok atau organisasi. Beberapa pendekatan yang dilakukan antara lain menggunakan tiga tahapan; pertama pembinaan (marhalah tasqif) yang kemudian dibentuk kader-kader organisasi politik, kedua tahap interaksi dengan masyarakat secara terbuka (marhalah ma'a al-ummah) disini kader diturunkan ditengah masyarakat. Mereka mengemukakan gagasannya dengan menjawab masalah-masalah yang muncul dengan simbol-simbol Islam misalnya ekonomi Islam, politik Islam, partai Islam dan seterusnya, sehingga Islam oleh masyarakat dianggap sebagai obat bagi segala persoalan masyarakat yang kompleks dan kontekstual. Ketiga, pengambilalihan kekuasaan (marhalah istilam al-hukm), setelah masyarakat diindoktrinasi dengan gagasan-gagasan yang diambil oleh Taqiyuddin Nabhani diharapkan masyarakat menuntut pemberlakuan syariah Islam dan didirikannya Negara Islam $^{33}$.

Penyampaian informasi atau pemikiran suatu gerakan untuk pencapaian maksud dan tujuan tertentu dapat dilakukan melalui media social dengan karakteristik $^{34}$ mulai dari partisipasi, keterbukaan, komunikasi, komunitas, ketergantungan/keterhubungan. Dengan demikian, indoktrinasi suatu paham agama dapat terserap oleh setiap individu sehingga menjadi sebuah identitas individu sampai identitas kelompok sebagai bentuk pemahaman seseorang untuk mengikuti dan melakukan apa yang menjadi kehendak daripada tujuan gerakan organisasi tersebut. Indoktrinasi ini sudah sangat mudah dilakukan

32 Petrus R.Golose, Deradikalisasi Terorisme Humanis dan Menyentuh Akar Rumput, (Jakarta: YPKIK, 2009), h. 42.

${ }^{33}$ Taqiyuddin An-Nabhani, Jalan Politik Hizbut Tahrir, Jakarta, 1992.

${ }^{34}$ Antony Mayfield, What Is Social Media, h. 6. 
baik secara langsung (tatap muka) ataupun secara online melalui media sosial yang mana sasaran dari gerakan tersebut adalah masyarakat akademisi. Dari sudut pandang interaksi sosial, media sosial menciptakan pemahaman baru mengenai komunikasi pribadi yang interaktif. Media sosial tidak seperti interaksi langsung (face to face), akan tetapi memberikan bentuk interaksi baru yang membawa penggunanya kembali pada hubungan interpersonal.

Sesuai dengan teori yang dikemukakan Syafi'i Ma'rif ${ }^{35}$ yang mengemukakan tiga teori berkenaan dengan munculnya kelompok fundamentalis dalam Islam, yaitu pertama, kegagalan umat Islam dalam menghadapi arus modernitas yang dinilai menyudutkan Islam kemudian berbalik mengadakan perlawanan terhadap modernitas dengan berbagai cara, seperti kondisi yang saling menghujat melalui penggunaan media lewat internet; kedua, munculnya solidaritas Islam terhadap nasib saudara di negara lain; ketiga, maraknya fundamentalisme di nusantara lebih disebabkan oleh kegagalan negara mewujudkan cita-cita kemerdekaan berupa tegaknya keadilan sosial dan terciptanya kesejahteraan yang merata bagi seluruh rakyat.

Secara kasat mata penulis menerangkan hal-hal yang dapat menyebabkan mudahnya seorang individu untuk terindoktrinasi paham tertentu, diantaranya karena faktor kebodohan, kemiskinan, politik, psikologis dan doktrin radikalisme. Hal ini sangat mudah dan rentan membawa seseorang untuk masuk dan mengikuti ideologi tertentu karena kondisi yang memaksa terutama faktor kemiskinan. Sekarang ini indoktrinasi mulai menyusur pada kaum cendekiawan intelektual, khususnya kaum muda yang haus akan pemahaman agama, sehingga mencari ketentraman hati dan pikiran dalam pencarian jati diri keagamaannya, salah satunya melalui organisasi sekolah/kampus juga rohis-rohis sekolah yang kemudian berlanjut pada pendidikan tinggi dan akhirnya menekuni lebih dalam secara tekun terhadap paham tertentu. Pada gerakan pemikiran Hizbut Tahrir anggotanya diwajibkan untuk mempelajari buku pedomannya yaitu "Pandangan Hidup Dalam Islam" yang ditulis oleh Taqiyuddin An-Nabhani ${ }^{36}$ yang mana dijelaskan dalam buku tersebut mulai dari hukum syara sampai pada sistem pemerintahan.

Direktur Deradikalisasi Irfan Idris ${ }^{37}$ menyatakan bahwa sistem pendidikan kita yang cenderung menggugurkan kewajiban, tidak

${ }^{35}$ Ahmad Syafi'i Ma'arif, "Masa Depan Islam di Indonesia dalam Abdurrahman Wahid (Ilusi Negara Islam)", (Jakarta: The Wahid Institute, 2009), h. 8-9.

${ }^{36}$ Taqiyuddin An-Nabhani, Peraturan Hidup Dalam Islam, (Jakarta: HTI Press, 2012).

${ }^{37}$ Irfan Idris. Direktur Deradikalisasi BNPT .Wawancara tanggal 13 Juli 2016 pukul 17.30 . 
memperkuat pemahaman wawasan kebangsaan dan tidak komprehensif dalam penyampaian pendidikan sejarah. Pada mahasiswa di PTAI yang salah arah biasanya yang berlatarbelakang SMA, masuk kampus menerima doktrin hitam putih, yang penting thogut, kafir, jihad dengan pemahaman yang dangkal. Melalui Kemenristek bekerjasama dengan BNPT, agar setiap kampus melalui pimpinan perguruan tinggi memberikan peringatan untuk mewaspadai mahasiswa yang mau membentuk Hizbut Tahrir yang jelas-jelas bertentangan dengan Pancasila, penanaman kebencian dan penyebaran permusuhan tidak ada dasar hukumnya. Lembaga organisasi internal kampus juga harus lebih hidup, ketimbang kegiatan-kegiatan pengkajian pahampaham tertentu. Sebuah Perguruan Tinggi harus mengingatkan kepada mahasiswa baru sebelum dibrainstorming oleh seniornya.

Dari cybercommunity yang terbangun di dalam cyberspace oleh kelompok gerakan Hizbut Tahrir jelas telah menyasar pada kaum akademisi khususnya pada mahasiswa. Ini akan terbangun identitas diri seorang individu yang akan melahirkan cyberculture dalam dirinya yang telah terinternalisasi dalam kehidupannya sehari-hari mulai dari cara pandang, pemikiran hingga pada perbuatan semua menuju pada satu identitas yaitu Hizbut Tahrir. Dijelaskan oleh Wenger ${ }^{38}$ bahwa komunitas merupakan kumpulan individu yang saling berbagi dan memiliki kepentingan yang sama terhadap suatu hal serta pengetahuan dengan cara berinteraksi secara terus-menerus. Komunikasi virtual yang terbentuk berada pada wilayah dunia maya, memungkinkan antar anggotanya tidak mengenal secara personal sebelumnya, hanya melalui media sosial saja.

Menurut Piere Levy, ${ }^{39}$ dunia maya (cyber) memiliki karakteristik tersendiri, yang menampilkan cara interaksi di dalam masyarakat modern. Kendall dalam Pramod ${ }^{40}$ menyatakan budaya dunia maya (cyberculture) terbentuk dalam hubungan dengan ruang sosial secara online. Tomic juga menjelaskan bahwa cyberculture ${ }^{41}$ merupakan budaya yang terbentuk melalui komunikasi yang tersaji sebagai ruang publik oleh individu, kelompok dan masyarakat. Demikian juga yang disampaikan oleh David Bell ${ }^{42}$ bahwa era

\footnotetext{
${ }^{38}$ Wenger, E., R McDermott\&W Snyder, Communities of Practice: Learning, Meaning, and Identity. (Cambridge, UK: Cambridge University Press, 2002), h. 42.

${ }^{39}$ Levy, Pierre, Cyberculture: Electronik Mediations. V. 4, (London: University of Minnesota Press, 2001), h. 259.

${ }^{40}$ Nayar K Pramod. The New Media and Cybercultures Anthology. (London: John Wiley and Sons, Incorporated, 2010), h. 534.

${ }^{41}$ Alice Tomic, Laura Lengel, Crispin Thurlow, Computer Mediated Communication Social Interaction and The Internet, (California: Sage Publications, 2004), h. 30.

${ }^{42}$ Bell, David. Cyberculture Theories Manuel Castells and Donna Haraway, (LondonNew York: Routledge, 2007), h. 36.
} 
digital ini merupakan wadah bagi masyarakat yang berinteraksi melalui internet sehingga membentuk cara pandang yang terintegrasi dengan teknologi informatika secara online atau realitas virtual. Dikatakan oleh Bakardjieva $^{43}$ bahwa kenyataan pada masyarakat dapat juga dilihat dari interaktifitas masyarakat dalam penggunaan internet seperti apa, apakah menjadi masyarakat konsumtif atau masyarakat yang bijak dalam penggunaan dan pemanfaatan internet. Hal ini mengharuskan masyarakat untuk terlibat aktif dalam memerankan fungsinya dalam proses sosial untuk menciptakan hubungan timbal balik yang berhubungan dengan pengetahuan dan kehidupannya. Dalam perspektif sosiologis, Azca ${ }^{44}$ mengemukakan penyebab individu atau kelompok terlibat dalam sebuah gerakan radikalisme adalah terjadinya krisis identitas yang menimpa kaum muda (youth). Hal inilah yang kemudian menyebabkan remaja mencari identitas dirinya dan mewujudkannya dalam gerakan Islam radikal. Kecenderungan ini yang mesti diwaspadai oleh semua pihak utamanya keluarga yang memiliki tanggungjawab terbesar, sehingga generasi muda tidak salah dalam memahami sebuah paham keagamaan yang bisa menjerumuskan seorang individu pada tindakan radikal.

Hasil focus group discussion dengan narasumber Supriyanto, ${ }^{45}$ dosen sekaligus sebagai Sekretaris MUI provinsi Sultra, menyampaikan beberapa hal penting yang perlu diperhatikan, diantaranya:

1. Ada kegelisahan secara nasional pada gerakan mahasiswa dimana lembaga kemahasiswaan mudah dipengaruhi oleh paham-paham keagamaan yang berkembang dan hidup pada masyarakat. Jika paham keagamaan sudah masuk pada lembaga kemahasiswaan,maka mahasiswa akanmenjadi kader-kader yang militan.

2. Doktrin agama kelompok tertentu melalui diskusi atau kajian-kajian menjadikan munculnya ekstrimisme-ekstrimisme pada segmen mahasiswa paham agama tertentu. Disinilah perlunya menjaga pilar dalam berbangsa dan bernegara yaitu Pancasila, UUD 1945, Bhineka Tunggal Ika.

3. Pemahaman keagamaan masyarakat kita ada dua pandangan, yaitu Islam formalisme dan Islam substansialisme Islam. Bila ada gerakan yang ingin mengganti ideologi Pancasila maka disebut Islam formalism, berupa

${ }^{43}$ Maria Bakardjieva. Internet Society: The Internet in Every Day Life. 1 edition. (London: Sage Publications Ltd, 2005), h. 103.

${ }^{44}$ Muhammad Najib Azca, "Yang Muda, Yang Radikal: Refleksi Sosiologis Terhadap Fenomena Radikalisme Kaum Muda Muslim di Indonesia Pasca Orde Baru", Jurnal MAARIF. Arus Pemikiran Islam Dan Sosial, Vol. 8 No 1. (Juli 2013): 14-44.

${ }^{45}$ Supriyanto, Tokoh MUI dan Dosen IAIN Kendari. Fokus Group Discussion, tanggal 15 Juni 2016. 
simbol-simbol Islam seperti syariat Islam, Negara Islam, bendera Arab dan sebagainya yang kemudian melahirkan eksklusifisme, intoleransi. Kedua, bentuk substansialisme Islam dimana Undang-undang yang berjiwa Islam dalam setiap pasalnya ada ruh Islam yang melahirkan inklusifisme.

4. Maraknya gerakan yang mengatasnamakan agama muncul karena beberapa hal seperti memudarnya pluralisme dan rasa nasionalisme. Salah satu sebabnya adalah dihapusnya perangkat yang berbau Pancasila sehingga terjadi diskontinyuiti dalam pengamalan Pancasila yang berakibat pada memudarnya nasionalisme. Tantangan Indonesia diantaranya adalah menguatnya konsumerisme, kekerasan atas nama agama, menipisnya pluralisme, ancaman terhadap disintegrasi, persatuan dan kesatuan mengalami kerapuhan.

5. Memahami perbedaan/pluralisme, melakukan deradikalisasi lembaga kemahasiswaan dengan cara jangan mengembangkan terlalu berlebihan terminologi jihad, memahami Islam inklusif, memahami perbedaan kultur/budaya, pendidikan karakter akan melahirkan inklusif, sikap toleran.

Konsepsi organisasi sebagai kolektifitas, seperti dikemukakan oleh Richard Scott dalam Winardi ${ }^{46}$ yang menyatakan bahwa organisasi diciptakan sebagai suatu kolektifitas yang sengaja dibentuk untuk mencapai suatu tujuan khusus tertentu yang sedikit banyak didasarkan pada asas kelangsungan aktivitas. Maka aktivitas gerakan organisasi Hizbut Tahrir sebagaimana dijelaskan Turkle ${ }^{47}$ yang menyelidiki keterhubungan antara pengguna dengan teknologi baru dimana ditemukan bahwa sebagian orang memperlakukan internet sebagai tempat peluapan emosi, artinya, ada kenyamanan pengguna dalam komunikasi online sebagai pengungkapan diri dan interaksi dengan media daripada langsung dengan manusia lain. Hal ini sebagaimana dinyatakan oleh Fixy Ferris dalam Effendi ${ }^{48}$ bahwa interaksi secara interpersonal yang dihubungkan melalui internet yaitu meliputi komunikasi langsung (synchronous) maupun tidak langsung (asynchronous), dimana penggunaan internet beserta fasilitas dan kemampuannya didayagunakan sebagai alat penyampai pesan baik bersifat massa maupun pribadi.

${ }^{46}$ Winardi. Teori Organisasi dan Pengorganisasian. Ed-1-4. Jakarta: PT. Raja Grafindo Persada, 2007, h.116.

47 Turkle S, The Second Self: Computers and the Human Spirit. (London: The MIT Press, 2005), h. 100.

${ }^{48}$ Effendi M, "Peranan Internet Sebagai Media Komunikasi", Jurnal Dakwah dan Komunikasi, Vol. 4 No.1, (2010): 130-142. 
Melalui sarana media sosial ini penggunaan dan pemanfaatan ruang maya (cyberspace) menjadi sangat luas dan sangat cepat dalam menghubungkan interaksi sosial secara interpersonal dan kemudian menciptakan suatu komunitas-komunitas yang beragam dari berbagai kepentingan dan ketertarikan pada isu-isu tertentu yang diserbarkan melalui internet. Dari sudut pandang interaksi sosial, media sosial seperti facebook dapat menciptakan pemahaman baru mengenai komunikasi pribadi yang interaktif. Media sosial tidak seperti interaksi langsung (face to face) akan tetapi memberikan bentuk interaksi baru yang membawa penggunanya kembali pada hubungan interpersonal, yaitu dalam bentuk interaksi termediasi melalui media sosial, dimana individu satu sama lain dapat berinteraksi secara realtime. Hal ini sebagaimana dijelaskaan Fixy Ferris dalam Effendi ${ }^{49}$, bahwa interaksi secara interpersonal yang dihubungkan melalui internet yaitu meliputi komunikasi langsung (synchronous) maupun tidak langsung (asynchronous), dimana penggunaan internet beserta fasilitas dan kemampuannya didayagunakan sebagai alat penyampai pesan baik bersifat massa maupun pribadi.

\section{Penutup}

Penggunaan newmedia internet melalui media social facebook digunakan oleh mahasiswa sebanyak $89 \%$ karena facebook lebih familiar pada penggunanya sedangkan pemanfaatan internet melalui media social sebagai sarana penyampaian informasi yang dilakukan dalam proses gerakan pemikiran Hizbut Tahrir dilakukan, melalui 1) cyberspace secara individu, secara interaksi antar individu dan secara komunitas; 2) cybersociety melalui masyarakat virtual dan 3) cyberculture melalui pembentukan budaya oleh gerakan pemikiran Hizbut Tahrir dengan simbol dan lainnya. Karakteristik media sosial dalam penyampaian informasi dapat dilakukan melalui beberapa cara yaitu partisipasi, keterbukaan, komunikasi, komunitas, dan ketergantungan/keterhubungan. Penyampaian informasi melalui media sosial yang dilakukan dengan 1) partisipasi dimana dilakukan oleh individu yang memang punya kesamaan pandangan dan pemikiran dengan gerakan organisasi Hizbut Tahrir; 2) keterbukaan dimana kegiatan dari organisasi Hizbut Tahrir dilakukan secara terbuka baik untuk individu maupun masyarakat melalui seminar dan kegiatan public lainnya; 3) komunikasi yang dilakukan secara personal maupun melalui media social yang ada sehingga apa yang menjadi tujuan dari gerakan Hizbut Tahrir dapat diterima oleh masyarakat luas dengan mengungkapkan pemikirannya seperti pada postingan tulisan-tulisannya pada media social facebook; 4) komunitas yaitu

${ }^{49}$ Ibid. 
bentuk dari gerakan Hizbut Tahrir yang ada di masyarakat secara luas yang telah diformalkan dalam peraturan pemerintah, meskipun sekarang telah ada pelarangan terhadap gerakan organisasi Hizbut Tahrir oleh pemerintah karena terindikasi menyeberang dari ideologi Pancasila, serta 5) ketergantungan/keterhubungan, yaitu suatu keadaan secara psikologis yang mempererat hubungan antara tiap individu dengan gerakan yang memiliki pandangan yang sama untuk menegakan khilafah sekalipun mendapat rintangan yang besar baik dari masyarakat maupun pemerintah. Melalui sarana media social ini, penggunaan dan pemanfaatan ruang maya (cyberspace) menjadi sangat luas dan sangat cepat dalam menghubungkan interaksi sosial secara interpersonal dan kemudian menciptakan suatu komunitas-komunitas yang beragam dari berbagai kepentingan dan ketertarikan pada isu-isu tertentu yang diserbarkan melalui internet. Dengan demikian, penggunaan internet dapat ditujukan untuk menyampaikan atau mensosialisasikan ajaran Islam dengan cara yang baik tanpa menjelekan ajaran lainnya, memberikan layanan informasi bagi masyarakat khususnya umat Islam dan sebagai alat penyeimbang terhadap informasi yang bersifat dan menyudutkan Islam.

\section{Daftar Pustaka}

An-Nabhani, Taqiyuddin. Peraturan Hidup Dalam Islam. Jakarta: HTI Press, 2001.

Alice, Tomic, Laura Lengel, \& Crispin Thurlow. Computer Mediated Communication Social Interaction and The Internet. California: Sage Publications, 2004.

Azca, Muhammad Najib, "Yang Muda, Yang Radikal: Refleksi Sosiologis Terhadap Fenomena Radikalisme Kaum Muda Muslim di Indonesia Pasca Orde Baru", Jurnal MAARIF. Arus Pemikiran Islam Dan Sosial, Vol. 8 No 1, (Juli, 2013): 14-44.

Badan Inteligen Nasional, Gerakan Islam Transnasional dan Pengaruhnya di Indonesia.

Bell, David. Cyberculture Theories: Manuel Castells and Donna Haraway. London-New York: Routledge, 2007.

Bakardjieva, Maria. Internet Society: The Internet in Every Day Life. 1 edition. California: Sage Publications Ltd, 2005.

Bungin, Burhan. Sosiologi Komunikasi Teori, Paradigma dan Diskursus Teknologi Komunikasi di Masyarakat. Jakarta: Kencana. 2006.

Castells, Manuel, The Power of Identity, Second Edition With A New Preface, Wiley-Blackwell, 2010). 
https://www.researchgate.net/publication/280831282_Networks_in_Ma nuel Castells' theory of the network society.

Effendi M. "Peranan Internet Sebagai Media Komunikasi". Jurnal Dakwah dan Komunikasi, Vol. 4 No.1 (2010): 130-142.

Golose, Petrus R. Deradikalisasi Terorisme Humanis dan Menyentuh Akar Rumput. Jakarta: YPKIK, 2009.

Iqbal, Asep Muhammd. "Agama dan Adopsi Media Baru: Penggunaan Internet Oleh Gerakan Salafisme di Indonesia”. Jurnal Komunikasi Indonesia. Vol 2. No. 2 (Oktober, 2013).

Levy, Pierre Cyberculture: Electronik Mediations. V. 4, (London: University of Minnesota Press. 2001)

Ma'arif, Ahmad Syafi'i. "Masa Depan Islam di Indonesia dalam Abdurrahman Wahid (Ilusi Negara Islam). Jakarta: The Wahid Institute, 2009.

Mayfield, Antony. What is Social Media?. London: Crossing. United Kingdom, http://www.iCrossing.com/ebooks.2008.h.5

Mustaqim, Muhammad. "Pergulatan Pemikiran Islam Di Ruang Publik Maya (Analisis terhadap Tiga Website Organisasi Islam di Indonesia)", Jurnal Penelitian, Vol. 7, No. 2, (Agustus 2013): 255-352

Poster, Mark. What's The Matter With The Internet. Minneapolis: University of Minoseta Press.2001, h.1-20.

Pramod, Nayar K. The New Media and Cybercultures Anthology. London: John Wiley and Sons, Incorporated, 2010.

Rafta, Yuni. "Sosial Network Analysis dalam Melihat Kecenderungan Pemberitaan Pada Akun Twitter "detikcom" dan "Metro_TV", Jurnal Khazanah. Vol 6 No. 2, (Januari 2014).

Simarmata, Salvatore. "Media Baru, Ruang Publik Baru dan Transformasi Komunikasi Politik di Indonesia”, Jurnal INTERACT, Vo.3 No.2, (November 2014): 18-36.

Wenger, E., R McDermott\&W Snyder. Communities of Practice: Learning, Meaning, and Identity. (Cambridge, UK: Cambridge University Press, 2002.

Turkle, S. The Second Self: Computers and the Human Spirit. London: The MIT Press, 2005.

Winardi. Teori Organisasi dan Pengorganisasian. Ed-1-4. Jakarta: PT. Raja Grafindo Persada, 2007.

Winarni, Leni, "Media Massa dan Isu Radikalisme Islam". Jurnal Komunikasi Massa. Vol 7. No.2, (Juli, 2014). 